\title{
Estudios Literarios
}

\section{Deconstruyendo un célebre soneto de Sor Juana}

\section{Christian Hopp*}

Procura desmentir los elogios que a un retrato de la poetisa inscribió la verdad, que llama pasión.

Este que ves, engaño colorido, que, del arte ostentando los primores, con falsos silogismos de colores es cauteloso engaño del sentido;

5 éste, en quien la lisonja ha pretendido excusar de los años los horrores, y venciendo del tiempo los rigores triunfar de la vejez y del olvido,

es un vano artificio del cuidado,

10 es una flor al viento delicada, es un resguardo inútil para el hado: es una necia diligencia errada, es un afán caduco y, bien mirado, es cadáver, es polvo, es sombra, es nada (Rivers, 2008, p. 386).

El título "Procura desmentir los elogios que a un retrato de la poetisa inscribió la verdad, que llama pasión" de este célebre soneto no proviene de la pluma de la excelsa poetisa mexicana Sor Juana Inés de la Cruz, sino de su editor, Alfonso Méndez Plancarte

Departamento de Educación en filología inglesa y filología española. Facultad de Filosofía y Filología de la Universidad Johannes Gutenberg de Maguncia, Alemania. Asistente científico en la cátedra de literatura iberorrománica del Seminario de Filología Románica. Examen complementario en filología latina. Dirección: Alte Mainzer Str. 42, D-64569, Nauheim, Alemania. Correo electrónico: c.hopp@gmx.ch 
(1909-1955). Con este título pretendió fijar para siempre la idea de que el "engaño colorido" (verso 1) es el retrato de la poetisa misma. Pero quitándole este título ajeno al soneto, bien cabe la interpretación de fuerte impronta deconstructivista de que la obra de arte que evoca el yo lírico sea el soneto mismo que el lector tiene ante sí.

Según las interpretaciones tradicionales, Sor Juana retoma en este soneto el tópico barroco de la vanitas mundi (imitando el soneto "Mientras por competir con tu cabello", de Góngora) y presenta la oposición entre la naturaleza sujeta al tiempo y el arte intemporal, advirtiéndole al lector de que un retrato es engañoso, porque en vez de mostrar los efectos del tiempo en la persona retratada, la muestra siempre bella y en eterna juventud. Vale la pena alejarse de esas interpretaciones e ir más allá de la idea de que el objeto sobre el cual el yo lírico llama la atención sea un retrato: aunque la expresión "engaño colorido" (v. 1) pertenece al campo semántico de la pintura, es un juego lícito conceptista sacarla de este campo semántico e implantarla en otro, donde el adjetivo colorido gana connotaciones como polifacético, variado, rico en impresiones, etc. Lo mismo pasa con los "falsos silogismos de colores" (v. 3), de carácter igualmente engañoso.

Cuando en el segundo cuarteto el yo lírico dice que "[é]ste" pretende "excusar de los años los horrores" (v. 5) y "triunfar de la vejez y del olvido" (v. 8), se refiere con "[é]ste" al poema mismo y quiere señalar la vanidad de la idea de que el poeta se inmortalice escribiendo una obra, como lo intentaron Ovidio y Horacio. El poema también es mortal y caduco; es todo lo que el yo lírico enumera en cada endecasílabo de los dos tercetos de carácter climático, antes de culminar en el verso final en el cual tres términos climáticos aún esfuerzan la graduación de la caducidad por ser cada vez más cortos: "es cadáver [cuatro sílabas], es polvo, es sombra, es nada" [tres sílabas] (v 14). El soneto consta de una sola oración simple que se puede condensar en "Éste (v. 1) [...] es nada" (v.14). El soneto mismo es nada ante el olvido, porque aunque los grafemas de la escritura sobreviven, el significado se pierde, debido al proceso de la différance (Derrida) ${ }^{1}$, según el cual cada palabra cambia su significado constantemente, dependiendo del contexto en el cual es usada. Por ende, escribir un poema es un "artificio vano" (v. 9) y no tiene sentido. La tercera palabra del poema es "ves" y no "lees" porque la escritura misma -según el pensamiento derridianocarece de un significado fijo y está abierta a cualquier interpretación.

Si se interpreta el soneto de esta manera, se descubre una modernidad casi inaudita. Como es sabido, todo arte moderno ha querido destruir la idea de la presencia y de la escritura como portadora de la realidad. Escritores como Jorge Luis Borges y Henri Michaux son tal vez los representantes más audaces de esta empresa. Escribiendo en el siglo XVII un poema como ejemplo mismo de la vanidad y declarándolo vacuo de significado y necesariamente ininteligible, Sor Juana anticipa conceptos de la literatura postmoderna y puede pasar por nuestra contemporánea.

El planteamiento más conciso de este concepto fundamental de la filosofía de Derrida se encuentra en Jacques Derrida (1968). 


\section{Referencias bibliográficas}

Derrida, J. (1968). La Differánce. Bulletin de la Société Française de Philosophie, 62, (3), 73-101.

Rivers, E. L. (Ed.). (2008). Poesía lírica del Siglo de Oro. Madrid: Cátedra, Mil Letras. 